\title{
PENGARUH METODE LATIHAN PUKULAN DAN KELINCAHAN TERHADAP KETERAMPILAN BERMAIN BULUTANGKIS ATLET TINGKAT PEMULA
}

\author{
THE EFFECT OF STROKE AND AGILITY EXERCISE METHOD \\ ON THE PLAYING BADMINTON SKILLS \\ OF BEGINNER LEVEL ATHLETES
}

\author{
Dhedhy Yuliawan, FX. Sugiyanto \\ SD Muhammadiyah Kleco Kotagede Yogyakarta, Universitas Negeri Yogyakarta \\ dhedhy_07@yahoo.com,fx.sugiyanto56@yahoo.co.id
}

\begin{abstract}
Abstrak
Penelitian ini bertujuan untuk mengetahui: (1) perbedaan pengaruh antara metode drill dan metode strokes terhadap keterampilan bermain bulutangkis atlet tingkat pemula, (2) perbedaan peningkatan keterampilan bermain bulutangkis antar atlet yang memiliki kelincahan tinggi dan kelincahan rendah, (3) interaksi antara metode latihan dan kelincahan terhadap keterampilan bermain bulutangkis atlet tingkat pemula. Penelitian ini menggunakan metode eksperimen dengan rancangan faktorial $2 \times 2$. Populasi dalam penelitian ini adalah atletklub PB. Manunggal, PB. Natura dan PB. Surya Mataram yang berjumlah 46 atlet. Besarnya sampel yang diambil sebanyak 24 atlet. Teknik analisis data penelitian ini menggunakan Uji t dan ANAVA. Hasil penelitian sebagai berikut: (1) ada perbedaan pengaruh yang signifikan antara metode drill dan metode strokes terhadap peningkatan keterampilan bermain bulutangkis, (2) ada perbedaan keterampilan bermain bulutangkis atlet pemula yang memiliki kelincahan tinggi dan kelincahan rendah, (3) tidak ada interaksi antara metode latihan dan kelincahan terhadap keterampilan bermain bulutangkis atlet tingkat pemula.
\end{abstract}

Kata Kunci: metode drill, metode strokes, kelincahan, bulutangkis

\begin{abstract}
This study aims to find out: (1) the difference in the effects of drill and strokes methods on the playing badminton skills, (2) the difference in the improvement of playing badminton skills between high and low agility, (3) the interaction between the exercise method and the agility on the improvement of playing badminton skills. The study employed the experimental method with $2 \times 2$ factorial design. The research population comprised 46 athletes from PB. Manunggal, PB. Natura and PB. Surya Matarm clubs. The sample, consisting of 24 athletes. The data in this study were analyzed using $t$ test and ANOVA. The results of the study are as follows: (1) There is a significant difference in the effects of drill and strokes methods on the playing badminton skills, (2) There is a significant difference in the improvement of playing badminton skills between high and low agility , (3) there is no interaction between the exercise method and the agility on the improvement of playing badminton skills.
\end{abstract}

Keywords: drill methods, stroke methods, agility, badminton 


\section{Pendahuluan}

Bulutangkis merupakan salah satu olahraga populer di dunia. Bulutangkis mampu memberikan peran dalam menyatukan sosialitas hampir di semua kalangan. Dalam bidang olahraga, bulutangkis merupakan salah satu cabang olahraga yang banyak dimainkan di masyarakat dalam berbagai tingkatan sosial. Bulutangkis dapat menembus masyarakat kalangan bawah sampai masyarakat kalangan atas. Hampir di setiap negara, bulutangkis mampu memberikan perannya yang positif untuk mengubah pandangan individu yang negatif menjadi satu hal yang dapat memberikan sumbangan karya.

Permainan bulutangkis adalah sebuah permainan dimana pelaksanaannya menggunakan alat yang disebut raket dan kok (Shuttle cock). Permainan dapat dilakukan satu lawan satu (single) atau dua lawan dua (doble). Raket adalah alat yang terbuat dari alumunium atau serat karbon yang berbentuk tongkat yang mempunyai kepala, dan pada bagian kepala tersebut terdapat senar yang dililitkan pada bagian kepala raket. Raket memiliki fungsi sebagai alat memukul kok. Kok adalah bulu angsa yang ditancapkan pada bagian pinggir gabus yang berbentuk setengah bola dan sebagai objek yang dipukul dalam permainan bulutangkis. Tujuan permainan bulutangkis sendiri adalah untuk memukul sebuah kok menggunakan raket, melewati net ke arah wilayah lawan, sampai lawan tidak dapat mengembalikannya.

Pemain bulutangkis yang handal diperlukan berbagai macam persyaratan, salah satunya adalah penguasaan teknik dasar permainan bulutangkis. Dalam cabang olahraga bulutangkis terdapat berbagai teknik dasar, di antaranya teknik service, smash, lob, drop, dan gerak kaki. Sebagaimana dikemukakan Purnama (2010, p.13) bahwa "Teknik dasar keterampilan bulutangkis yang harus dikuasai pemain bulutangkis antara lain: (1) sikap berdiri (stands) (2) teknik memegang raket, (3) teknik memukul bola, (4) teknik langkah kaki (Footwork)..

Dalam rangka mencapai kemampuan teknik bulutangkis dibutuhkan komponen-komponen fisik yang menunjang untuk tercapainya prestasi tinggi. Pemain bulutangkis dituntut mengembangkan komponen fisik: (1) Kelincahan, (2) dayatahan otot lokal, (3) dayatahan cardiovascular, (4) kekuatan, (5) power, (6) kecepatan, (7) fleksibilitas, (8) komposisi tubuh (Purnama, 2010, p.1). Sehubungan dengan pengembangan faktor-faktor kondisi fisik tersebut, maka diharapkan mampu memberikan peningkatan dalam keterampilan bermain bulutangkis.

Dalam upaya pencapaian prestasi tinggi, di Indonesia terdapat Perkumpulan Bulutangkis (PB) di setiap daerah. Di Perkumpulan Bulutangkis memberikan pelatihan-pelatihan yang intensif untuk menciptakan atlet-atlet handal agar mampu berperan dalam pencapaian prestasi perbulutangkisan di Indonesia. Upaya meningkatkan prestasi di PB Manunggal Bantul, PB Surya Mataram, PB Natura sudah dilaksanakan, di antaranya peningkatan fisik, teknik, mental dan pelatihan secara rutin. Selain itu PB Manunggal Bantul, PB Surya Mataram, dan PB Natura juga telah menghasilkan atletatlet berprestasi dan mengikuti kejuaraankejuaraan. Sehubungan anak latih dari Perkumpulan Bulutangkis cukup banyak dan bermacam-macam tingkat keterampilannya, maka masing-masing Perkumpulan Bulutangkis memberikan kelas-kelas latihan pada atletnya. Mengingat keterampilan atlet di Pekumpulan Bulutangkis tersebut berbeda-beda. Pelaksanaan pelatihan di PB Manunggal Bantul, PB Surya Mataram, dan PB Natura klasifikasi kelas atlet dibeda-bedakan menurut kelas masing-masing.

Dalam penelitian ini diharapkan mampu memberikan pengetahuan dalam materi latihan yang sesuai dengan siswa tingkatan pemula dalam pencapaian keterampilan bulutangkis sehingga mampu berkembang ke tingkatan berikutnya. Mengingat kondisi di lapangan pelatih memberikan pelatihan yang cenderung monoton untuk atlet tingkat pemula. Selain itu dalam pelaksanaan latihan pelatih kurang memperhatikan tentang prinsip-prinsip latihan sehingga pelatih hanya menitikberatkan pada latihan fisik, sehingga latihan teknik lebih sedikit diberikan dalam pelatihan. Materi latihan teknik yang diberikan yang lebih sering adalah metode latihan drill dan metode latihan strokes. Pelatihan dalam Perkumpulan Bulutangkis yang diberikan sudah sesuai dengan materi latihan yang dianjurkan. Dalam melatihkan keterampilan pukulan, perkumpulan menggunakan metode latihan drill dan latihan strokes. Latihan drill adalah latihan yang terpusat pada satu materi dan menitik beratkan pada pengulangan. Sedangkan latihan strokes dalam bulutangkis adalah suatu pola pukulan atau berbagai materi latihan yang dirangkai dalam satu rangkaian sehingga menghasilkan pola pukulan.

Sistem pelatihan dalam Perkumpulan Bulutangkis yang sering digunakan untuk melatih keterampilan teknik pukulan dengan 
menggunakan pendekatan metode latihan drill. Sedangkan untuk metode strokes lebih sedikit diberikan dalam porsi latihan. Dalam pelatihan pelatih memberikan porsi yang sama antara tingkatan atlet pada saat latihan menurut keterampilan bukan menurut klasifikasi umur. Penelitian ini diharapkan dapat memberikan bukti tentang efisiensi metode latihan yang digunakan untuk melatihkan keterampilan pukulan dan dapat memberikan porsi latihan yang tepat pada setiap tingkatan usia khususnya pada usia pemula. Melihat dalam sistem pelatihan di perkumpulan bulutangkis yang berada di daerah pinggiran cenderung monoton dan kurang memerhatikan prinsip-prinsip latihan yang sesuai dengan kondisi di lapangan. Melalui penelitian ini diharapkan juga dapat memberikan pengertian tentang metode latihan yang efektif dan efisien dalam melatihkan keterampilan bermain bulutangkis atlet tingkat pemula.

Dalam penelitian ini dapat didapatkan rumusan masalah sebagai berikut: (1) Adakah perbedaan pengaruh antara metode latihan drill dan metode latihan strokes terhadap keterampilan bermain bulutangkis atlet tingkat pemula?, (2) Adakah perbedaan peningkatan keterampilan bermain bulutangkis antara atlet yang memiliki kelincahan tinggi dan kelincahan rendah?, (3) Adakah interaksi antara metode latihan pukulan dan kelincahan terhadap keterampilan bermain bulutangkis atlet pemula? Penelitian ini diharapkan juga bermanfaat untuk menunjukkan bukti-bukti secara ilmiah mengenai pengaruh metode latihan pukulan dan kelincahan terhadap keterampilan bulutangkis atlet tingkat pemula, sehingga dapat dijadikan sebagai salah satu alternatif untuk menyususun program latihan teknik kepada pemain muda.

Latihan, Bulutangkis, Metode Drill, Metode Stroke, dan Kelincahan

Menurut Iriyanto (2002, pp.11-12) latihan adalah proses pelatihan dilaksanakan secara teratur, terencana, menggunakan pola dan sistem tertentu, metodis serta berulang seperti gerakan yang semula sukar dilakukan, kurang koordinatif menjadi semakin mudah, otomatis, dan reflektif sehingga gerak menjadi efisien dan itu harus dikerjakan berkali-kali. Birch, MacLaren, dan George (2005, p.1) menjelaskan bahwa "exercise physiology is the dicipline involving the examination of how physical activity, exercise influences the structure and function of the human body. Pada prinsipnya latihan merupakan suatu proses perubahan ke arah yang lebih baik, yaitu untuk meningkatkan: kualitas fisik, kemampuan fungsional peralatan tubuh, dan kualitas psikis anak latih (Sukadiyanto, 2005, p.1).

Olahraga bulutangkis atau badminton merupakan salah satu cabang olahraga yang sudah dikenal masyarakat secara luas, baik di dalam negeri maupun di luar negeri. PBSI (2001, p.9) menjelaskan bahwa "permainan bulutangkis adalah upaya untuk memasukkan kok ke bidang permainan lawan, tanpa kok itu tidak bisa dikembalikan". Bulutangkis adalah permainan yang menggunakan alat untuk pelaksanaannya. Subarjah (2000, p.13) "tujuan permainan bulutangkis adalah berusaha untuk menjatuhkan kok di daerah permainan lawan dan berusaha agar lawan tidak dapat memukul kok dan menjatuhkannya ke daerah permainan sendiri”.

Bulutangkis dapat dilakukan satu lawan satu atau dua lawan dua. Davis (1997, p.20) mengemukakan bahwa "badminton can be played as single or doubles, either men's, women's or mixed". Inti permainan bulutangkis adalah untuk mendapatkan poin dengan cara memasukkan shuttlecock ke bidang lapangan lawan yang dibatasi oleh jaring (net) setinggi 1,55 meter dari permukaan lantai, yang dilakukan atas dasar peraturan permainan tertentu. Lapangan bulutangkis berukuran $610 \mathrm{~cm} \mathrm{x}$ $1340 \mathrm{~cm}$ yang dibagi dalam bidang-bidang, masing-masing dua sisi berlawanan dengan dibatasi oleh jaring (net). Ada garis tunggal, garis ganda, dan ada ruang yang memberi jarak antara pelaku dan penerima service.

Permainan bulutangkis dapat berjalan dengan baik jika pemain memiliki keterampilan bermain yang baik juga. Keterampilan bermain didapatkan dari penguasaan teknik bermain seorang pemain. Purnama (2010, p.13) bahwa "teknik dasar yang harus dikuasai oleh seorang pemain bulutangkis antara lain: sikap berdiri (stance) teknik memegang raket, teknik memukul bola, dan teknik langkah kaki (Footwork)". Sedangkan Subarjah (2000, p.21) bahwa "teknik dasar permainan bulutangkis yang perlu dipelajari secara umum dapat dikelompokan kedalam beberapa bagian yaitu: (a) cara memegang raket (grips) (b) Stance (sikap berdiri) (c) Footwork (gerakan kaki) (d) Pukulan (Strokes). Selain dari teknik dasar yang disebutkan, tetapi juga melibatkan teknik yang berkaitan dengan permainan bulutangkis". Pada intinya teknik pada bulutangkis adalah satu 
kesatuan dari pegangan raket, sikap berdiri, gerakan kaki dan pukulan.

Drill merupakan suatu cara mengajar dengan memberikan latihan-latihan terhadap apa yang telah dipelajari atlet sehingga memperoleh suatu keterampilan tertentu. Kata latihan mengandung arti bahwa sesuatu itu selalu diulang-ulang. Bila situasi latihan diubah-ubah kondisinya sehingga menuntut respons yang berubah, maka keterampilan akan lebih disempurnakan (Tahmid, 2009). Latihan pola pukulan ini dilakukan secara sederhana terlebih dahulu, yaitu dengan cara saling memberi umpan yang sederhana dan mudah. Permainan bulutangkis adalah olahraga yang membutuhkan keterampilan yang bagus dalam pelaksanaannya. Di samping menguasai keterampilan yang bagus, pemain dituntut memiliki kondisi fisik yang prima dan faktor yang menunjang dalam keberhasilannya. Bulutangkis mempunyai ciri gerakan yang eksplosif dan sewaktu-waktu dapat berubah sesuai dengan kondisi permainan.
Untuk itu pemain diwajibkan memiliki kondisi yang bagus dan keterampilan yang menunjang.

Subarjah (2011, p.33) menjelaskan bahwa "untuk dapat memainkan permainan bulutangkis dengan baik seorang pemain harus mampu melakukan beberapa teknik pukulan atau keterampilan gerak memukul". Dalam pengertian stroke adalah keterampilan dalam memukul kok atau sering disebut teknik pukulan bulutangkis. Metode latihan yang digunakan untuk melatihkan pukulan dalam permainan bulutangkis yaitu metode drill dan metode strokes. Masing-masing metode latihan tersebut memiliki kelemahan dan kelebihan masingmasing. Melihat gerakan yang dilakukan dalam metode drill dan metode strokes dalam melatihkan pukulan bulutangkis, dapat dianalisis kelemahan dan kelebihan dari metode latihan tersebut. Secara teoritis metode strokes lebih baik daripada metode drill. Menurut analisis dari pendapat sebelumnya tentang metode latihan drill dan metode latihan strokes terdapat perbedaan yang dapat dilihat pada tabel berikut:

\begin{tabular}{|c|c|}
\hline Metode drill & Metode strokes \\
\hline $\begin{array}{l}\text { Latihan dilakukan secara berulang-ulang untuk satu } \\
\text { tugas terlebih dahulu }\end{array}$ & $\begin{array}{l}\text { Latihan dilakukan secara berulang, tapi tersusun dalam } \\
\text { satu rangkaian gerakan. }\end{array}$ \\
\hline $\begin{array}{l}\text { Dalam latihan otot dominan yang bekerja akan terlatih } \\
\text { secara terpusat }\end{array}$ & $\begin{array}{l}\text { Otot yang bekerja menyeluruh, karena dalam satu tugas } \\
\text { atau rangkaian terdapat gerakan bermacam-macam }\end{array}$ \\
\hline $\begin{array}{l}\text { Konsentrasi pada latihan drill dalam memukul kok } \\
\text { terpusat dalam satu gerakan. }\end{array}$ & $\begin{array}{l}\text { Konsentrasi dalam metode strokes tidak terpusat, } \\
\text { karena gerakannya bermacam-macam.. }\end{array}$ \\
\hline $\begin{array}{l}\text { Anak latih akan merasakan kebosanan, karena } \\
\text { pengulangan diselesaikan dalam satu tugas terlebih } \\
\text { dahulu. }\end{array}$ & $\begin{array}{l}\text { Tingkat kebosanan anak latih sedikit, karena gerakan } \\
\text { bervariasi. }\end{array}$ \\
\hline $\begin{array}{l}\text { Anak latih dapat mengerti dan menguasai teknik } \\
\text { pukulan yang benar. }\end{array}$ & $\begin{array}{l}\text { Anak latih dapat mengaplikasikan langsung pukulan } \\
\text { yang dilatihkan seperti kenyataan. }\end{array}$ \\
\hline $\begin{array}{l}\text { Kesalahan teknik pukulan yang dilakukan anak latih } \\
\text { akan segera diketahui pelatih dan langsung dapat } \\
\text { dibetulkan }\end{array}$ & $\begin{array}{l}\text { Perlu membutuhkan waktu yang relatif lama, karena } \\
\text { tugas adalah satu gerakan rangkaian. }\end{array}$ \\
\hline $\begin{array}{l}\text { Pelatih selalu dapat mengawasi atau memonitoring } \\
\text { pelaksanaan latihan }\end{array}$ & $\begin{array}{l}\text { Pelatih dapat memberikan intruksi setelah rangkaian } \\
\text { gerakan terselesaiakan }\end{array}$ \\
\hline
\end{tabular}

Kelincahan merupakan salah satu unsur kondisi fisik yang berperan penting terutama pada cabang olahraga permainan termasuk bulutangkis, khususnya pada saat mengejar kok ke depan maupun ke belakang. Kelincahan adalah kemampuan seseorang untuk dapat mengubah arah dengan cepat dan tepat pada waktu bergerak tanpa kehilangan keseimbangan. Kelincahan ini berkaitan erat antara kecepatan dan kelentukan. Tanpa unsur keduanya baik, seseorang tidak dapat bergerak dengan lincah. Selain itu, faktor keseimbangan sangat berpengaruh terhadap kemampuan kelincahan sese- orang. Menurut Gibney (2011, p.20) bahwa "Agility is Generally an expression of excellent movement. More specifically described as the combined sum of strength, speed, balance, flexibility and all other athletic abilities". Sedangkan dari sumber lain kelincahan (agility) adalah kemampuan seseorang untuk dapat mengubah arah dengan cepat dan tepat pada waktu bergerak tanpa kehilangan keseimbangan (Sutrisna dan Khafadi, 2010, p.139). Menurut Ismaryati (2008, p.76) bahwa "kelincahan didefiniskan sebagai kemampuan untuk mengubah kecepatan dan arah posisi tubuh atau bagianbagiannya dengan cepat dan tepat, sementara 
perpindahannya dengan cepat tanpa kehilangan keseimbagan”. Sedangkan Widiastuti (2011, p125) menuliskan bahwa "agility atau kelincahan adalah kemampuan untuk mengubah arah atau posisi tubuh dengan cepat yang dilakukan bersama-sama dengan gerakan lainnya". Jika dilihat dari pendapat tersebut dapat disimpulkan bahwa kelincahan adalah kemampuan seseorang dalam merubah arah dan posisi tubuhnya dengan cepat dan tepat pada waktu bergerak, sesuai dengan situasi dan kondisi yang dihadapai di lapangan tertentu tanpa kehilangan keseimbangan tubuh.

Kelincahan juga dipengaruhi oleh beberapa faktor, yaitu: Ada beberapa faktor yang mempengaruhi kelincahan yaitu kekuatan otot, kecepatan, tenaga ledak otot, waktu reaksi, keseimbangan, dan koordinasi. Kelincahan merupakan salah satu komponen motorik yang sangat diperlukan untuk semua aktivitas yang membutuhkan kecepatan perubahan posisi tubuh dan bagian-bagiannya. Kelincahan termasuk suatu gerak yang rumit, di mana dalam kelincahan unsur-unsur yang lain seperti kelentukan, koordinasi dan kecepatan yang bereaksi secara bersamaan. Kelincahan ditentukan oleh faktor kecepatan bereaksi, kemampuan untuk menguasai situasi dan mampu mengendalikan gerakan secara tiba-tiba. Kelincahan diperlukan pada cabang olahraga yang bersifat permainan. Kelincahan berkaitan dengan gerak tubuh yang melibatkan gerak kaki dan perubahan perubahan yang cepat dari posisi badan. Kelincahan pada prinsipnya berperan untuk aktivitas yang melibatkan gerak tubuh yang berbah-ubah dengan tetap memelihara keseimbangan. Seorang atlet atau pemain yang mempunyai kelincahan yang baik maka akan mampu melakukan gerakan dengan lebih efektif dan efisien. Di samping itu kelincahan merupakan prasyarat untuk mempelajari dan memperbaiki keterampilan gerak dan teknik olahraga, terutama gerakan-gerakan yang membutuhkan koordinasi gerakan.

Istilah keterampilan juga sebagai suatu perbuatan atau tugas, dan sebagai indikator dari suatu tingkat kemahiran. Suatu keterampilan dianggap sebagai aktivitas gerak atau suatu tugas akan terdiri dari sejumlah respon gerak dan persepsi yang didapat melalui belajar untuk mencapai tujuan tertentu. Mahendra (2005, p.99) menjelaskan bahwa "penguasaan suatu keterampilan motorik merupakan sebuah proses di mana seseorang mengembangkan seperangkat respon gerak yang terkoordinasi, terorganisir, dan terintegrasi". Faktor-faktor yang mempengaruhi kelincahan seorang adalah kecepatan reaksi, kemampuan berorientasi terhadap problem yang dihadapi, kemampuan mengatur keseimbangan, kelentukan persendian, dan kemampuan mengerem gerakan-gerakan motorik. Jadi bisa disimpulkan keterampilan merupakan gambaran kemampuan motorik seseorang ditunjukkan melalui penguasaan suatu gerakan dalam olahraga.

\section{Kerangka Berpikir}

Permainan bulutangkis merupakan permainan yang membutuhkan keterampilan bermain yang dipengaruhi oleh beberapa faktor. Faktor dari setiap individu dapat mempengaruhi keberhasilan latihan. Disamping itu faktor dari pelatih dan metode latihan juga berpengaruh dalam meningkatkan keterampilan bermain. Metode latihan yang digunakan dalam meningkatkan keterampilan bermain bulutangkis adalah metode latihan pukulan yang terdiri dari metode drill dan metode stroke. Porsi latihan yang berbeda dalam penggunaan metode latihan tersebut menjadikan dasar masalah penelitian tersebut. Kedua metode latihan ini memberikan pengaruh dalam meningkatkan keterampilan pukulan dalam permainan bulutangkis. Penggunaan metode latihan pukulan yang tepat akan berpengaruh dalam meningkatkan keterampilan bermain bulutangkis. Sehingga terdapat perbedaan pengaruh antara metode drill dan metode stroke terhadap peningkatan bermain bulutangkis.

Kelincahan juga merupakan salah satu komponen penting dalam permainan bulutangkis. Komponen fisik dalam bulutangkis bermacam-macam, dan kelincahan adalah salah satu komponen dalam menunjang keberhasilan permainan bulutangkis yang baik. Kelincahan berperan penting dalam gerak bulutangkis. Mengingat bulutangkis adalah permainan yang menggunakan gerak yang eksplosif dan membutuhkan gerak cepat secara tiba-tiba, maka kelincahan berperan untuk keberhasilan gerakan tersebut. Sehingga ada perbedaan peningkatan keterampilan bermain bulutangkis antara atlet yang memimiliki kelincahan tinggi dengan kelincahan rendah.

Metode latihan pukulan untuk meningkatkan keterampilan bulutangkis harus didukung dengan komponen fisik kelincahan. Kelincahan yang baik mempengaruhi hasil keterampilan bermain bulutangkis. Karena kelincahan 
akan mempunyai pengaruh yang positif dalam keberhasilan permainan bulutangkis dan teknik pukulan yang efektif dan efisien. Dengan metode latihan pukulan dengan didukung kelincahan yang baik, maka akan mempengaruhi keterampilan bermain bulutangkis. Sehingga ada interaksi antara metode latihan pukulan dan kelincahan terhadap keterampilan bermain bulutangkis.

\section{Hipotesis Penelitian}

Berdasarkan kajian teori dan kerangka berpikir maka diajukan hipotesis penelitian sebagai berikut: (1)Ada perbedaan pengaruh keterampilan bermain bulutangkis antara metode latihan drill dan metode latihan stroke, (2) Ada perbedaan peningkatan keterampilan bermain bulutangkis antara atlet yang memiliki kelincahan tinggi dan kelincahan rendah, (3) Ada interaksi antara metode latihan dan kelincahan terhadap keterampilan bermain bulutangkis atlet pemula.

Desain Penelitian

Penelitian yang dilakukan ini termasuk dalam penelitian eksperimen dengan menggunakan rancangan faktorial 2 × 2 . Menurut Ary, Jacobs, Razavieh (2007, p.389) masing-masing dari kedua variabel bebas itu memunyai dua nilai.

\section{Variable Penelitian}

Variabel dalam penelitian ini meliputi dua variabel yaitu variabel bebas manipulatif yaitu metode latihan pukulan yang terdiri dari 2 sel variabel, yaitu: (a) Metode latihan drill, dan (b) Metode latihan strokes dan variabel bebas atributif (yang dikendalikan) dalam penelitian ini yaitu: (a) Kelincahan tinggi, dan (b) Kelincahan rendah. Sedangkan variabel terikatnya adalah keterampilan bermain bulutangkis atlet pemula.

Waktu dan Tempat Penelitian

Penelitian akan dilaksanakan di PB Surya Mataram, PB Natura dan PB Manunggal Bantul. Penelitian dilaksanakan pada tanggal 15 Juni-16 Juli 2013, pada hari Senin, Rabu, Jumat dan Sabtu untuk Kelompok A1B1 dan A1B2 dengan 1 kali pretest, 16 kali latihan dan 1 kali posttest.

\section{Populasi dan Sampel Penelitian}

Penelitian ini menggunakan populasi seluruh anak latih tingkat Pemula yang aktif latihan PB Surya Mataram, PB Natura dan PB Manunggal Bantul, yang berjumlah sebanyak 46 anak latih putra. Terdiri dari 24 anak latih berada di PB. Manunggal, 10 anak latih berada di PB. Surya Mataram dan 12 anak latih di PB. Natura.

Besar sampel yang akan digunakan dalam penelitian ini adalah $27 \%$ batas atas dan $27 \%$ batas bawah setelah dilakukan tes kelincahan pada populasi (Miller 2002, p.68). Berdasarkan klasifikasi tesebut didapatkan 6 anak latih dengan kelincahan tinggi, 6 anak latih kelincahan rendah pada PB. Manunggal dan 6 anak latih kelincahan tinggi, 6 anak latih kelincahan rendah pada PB. Surya Mataram dan PB. Natura. Penelitian ini dibagi menjadi 4 kelompok perlakuan, kelompok 1 metode drill dengan kelincahan tinggi (A1B1) dipandu oleh seorang pelatih dilaksanakan di PB Manunggal Bantul, kelompok 2 metode strokes dengan kelincahan tinggi (A1B2) dipandu oleh seorang pelatih dilaksanakan di PB Manunggal Bantul, Kelompok 3 metode drill dengan kelincahan rendah (A2B1) dipandu oleh dua orang pelatih dilaksanakan di PB Surya Mataram dan PB Natura, kelompok 4 metode strokes dengan kelicahan rendah (A2B2) dpandu oleh dua orang pelatih dilaksanakan di PB Surya Mataram dan PB Natura. Dalam pelaksanaan program latihan pelatih diundi secara random sehingga setiap pelatih mempunyai peluang yang sama dalam mengawasi anak latih dalam pelaksanaan program latihan.

\begin{tabular}{ccc}
\hline \multirow{2}{*}{ Kelincahan } & \multicolumn{2}{c}{ Metode latihan } \\
\cline { 2 - 3 } & $\begin{array}{c}\text { Metode Drill } \\
(\mathbf{a 1})\end{array}$ & $\begin{array}{c}\text { Metode Strokes } \\
(\mathbf{a 2})\end{array}$ \\
\hline $\begin{array}{c}\text { Tinggi (b1) } \\
\text { Rendah } \\
\text { (b2) }\end{array}$ & 6 atlet & 6 atlet \\
\hline
\end{tabular}

Teknik Pengumpulan Data

\section{Data Kelincahan}

Instrumen kelincahan adalah menggunakan agility test dengan ukuran jarak lari setengah bagian dari lapangan bulutangkis (Purnama, 2010, p.3). Langkah-langkah dari pelaksanaan tes tersebut adalah: (a) Testee bergerak dari titik A dengan start melayang, (b) Testee berlari sprint ke arah titik B, C, D dan kembali ke titik A, (c) Sprint dilakukan dua kali putaran melewati titik serperti pada putaran pertama, (d) Waktu dimulai saat tester memberi aba-aba "ya" dan berhenti saat testee selesai dua kali putaran setelah melewati titik D, (e) 
Waktu yang dicatat menunjukkan hasil tes. Satuan dari hasil tes kelincahan adalah detik atau waktu.

\section{Data Keterampilan Bermain Bulutangkis}

Instrumen dalam pengambilan data keterampilan bermain bulutangkis memakai tes keterampilan milik Verducci yang diambil dari Purnama (2010, p.29).

\section{Teknik Analisis Data}

Setelah peneliti melakukan penelitian dan semua data terkumpul, maka teknik analisis data menggunakan teknik analisis varian (anava) dua jalur pada $\alpha=5 \%$. Jika $\mathrm{F}$ yang diperoleh $\left(\mathrm{F}_{0}\right)$ signifikan analisis dilanjutkan dengan uji perbedaan seluruh kelompok dan antar dua kelompok yaitu dengan Uji $t$ dan Anava dua jalur. Untuk memenuhi asumsi dalam teknik anava, maka sebelumnya dilakukan uji normalitas dengan uji Lilliefors dan uji Homogenitas varians dengan uji Bartlett.

\section{Hasil dan Pembahasan}

Penelitian ini terdiri dari 1 variabel penelitian, yaitu Keterampilan bermain bulutangkis. Adapun data penelitian yang terkumpul terdiri dari 4 kelompok data, yaitu kelompok A1B1 yang diberikan latihan dengan metode latihan drill dengan kelincahan tinggi, kelompok A1B2 yang diberikan latihan dengan metode latihan drill dengan kelincahan rendah, kelompok A2B1 yang diberikan latihan dengan metode latihan strokes dengan kelincahan tinggi, dan kelompok A2B2 yang diberikan

Latihan dengan metode latihan strokes dengan kelincahan rendah. Semua kelompok data terdiri dari data selisih pre test dengan post test, yaitu nilai peningkatan dari saat pretest dan setelah posttest. Deskripsi data akan menyajikan nilai maksimum, nilai niminum, mean, median, modus, dan standar deviasi dari data yang terkumpul. Dengan demikian gambaraan data akan terlihat jelas. Selain itu juga akan mudah membandingkan antara kelompok yang satu dengan kelompok yang lain.

Berikut hasil deskriptif data penelitian yang diperoleh dari analisis Frekuensi:

\section{Kelompok A1B1}

Deskripsi data kelompok A1B1 dengan metode latihan drill dengan kelincahan tinggi memperoleh nilai maksimum $=39,57$; nilai minimum $=9,12 ;$ mean $=22,29 ;$ median $=$
17,58; modus $=9,12$ dan nilai standar deviasi $=$ 11,92 .

\section{Kelompok A1B2}

Deskripsi data kelompok A1B2 dengan metode latihan drill dengan kelincahan rendah memperoleh nilai maksimum $=37,82$; nilai minimum $=-15,59 ;$ mean $=3,44 ;$ median $=$ 2,57; $\operatorname{modus}=-15,59$ dan nilai standar deviasi $=19,87$.

\section{Kelompok A2B1}

Deskripsi data kelompok A2B1 dengan metode latihan strokes dengan kelincahan tinggi memperoleh nilai maksimum $=19,81$; nilai minimum $=-15,57 ;$ mean $=1,12 ;$ median $=0,11$; modus $=-15,57$ dan nilai standar deviasi $=$ 13,66 .

\section{Kelompok A2B2}

Deskripsi data kelompok A2B2 dengan metode latihan strokes dengan kelincahan rendah memperoleh nilai maksimum $=-7,02$; nilai minimum $=-46,45 ;$ mean $=-26,84 ;$ median $=-$ 29,$43 ;$ modus $=-46,45$ dan nilai standar deviasi $=13,23$.

Uji Pra Syarat

Uji normalitas dilakukan menggunakan rumus Liliefors dengan program SPSS16. Data dikatakan berdistribusi normal apabila nilai signifikansi yang diperoleh lebih besar dari 0,05 . Berikut akan disajikan hasil uji normalitas yang diperoleh.

\begin{tabular}{cccc}
\hline $\begin{array}{c}\text { Variabel/ } \\
\text { Kelompok }\end{array}$ & Liliefors & Sig & Ket \\
\hline A1B1 & 0,284 & 0,141 & Normal \\
A1B2 & 0,273 & 0,182 & Normal \\
A2B1 & 0,224 & 0,200 & Normal \\
A2B2 & 0,230 & 0,200 & Normal \\
\hline
\end{tabular}

Uji homogenitas dilakukan pada kedua kelompok data yang hendak diuji beda. Uji homogenitas dalam penelitian ini menggunakan Levene. Kriteria pengambilan keputusan diterima apabila nilai nilai $\mathrm{p}>0,05$. Berikut hasil uji homogenitas yang diperoleh:

\begin{tabular}{cccc}
\hline Variabel & $\begin{array}{c}\text { Levene } \\
\text { Statistic }\end{array}$ & Sig & Ket \\
\hline A1B1 & & & \\
A1B2 & 0,750 & 0,535 & Homogen \\
A2B1 & & & \\
A2B2 & & & \\
\hline
\end{tabular}


Berdasarkan tabel tersebut, hasil uji homogenitas menunjukkan bahwa nilai signifikansi atau nilai probability ( $p$ ) yang diperoleh lebih besar dari 0,05 $(p>0,05)$. Dengan demikian maka dapat disimpulkan bahwa varians data dalam penelitian ini adalah homogen.

Hasil Analisis Data

Analisis data dalam penelitian ini menggunakan 2 cara, yaitu uji t dan Anava. Uji $\mathrm{t}$ digunakan untuk mengetahui perbedaan dari kedua kelompok data, sementara Uji Anova digunakan untuk mengetahui perbedaan dari keempat kelompok. Perbedaan antar kelompok ini dapat dikethui juga latihan mana yang paling efektif untuk meningkatkan keterampilan bermain bulutangkis seseorang. Hasil analisis dikatakan signifikan apabila nilai signifikansi yang diperoleh lebih kecil dari 0,05 ( $\mathrm{p}<0,05)$.

\section{Perbedaan Pengaruh Latihan Metode Drill dan Latihan Strokes terhadap Keterampilan Bermain Bulutangkis}

Hipotesis pertama berbunyi "ada perbedaan pengaruh latihan metode drill dan latihan strokes terhadap keterampilan bermain bulutangkis". Dalam uji ini menggunakan uji t, dengan kriteria pengujian adalah apabila nilai Sig lebih besar dari 0,05. diperoleh nilai $t$ hitung sebesar 3,324 dengan nilai Signifikansi 0,003 . Hasil penghitungan tabel nilai Sig yang diperoleh lebih kecil dari 0,05, dengan demikian dapat disimpulkan bahwa hipotesis diterima, artinya ada perbedaan pengaruh latihan metode drill dan latihan strokes terhadap keterampilan bermain bulutangkis.

\section{Perbedaan Peningkatan Keterampilan Bermain Bulutangkis antara Kelincahan Tinggi dan Kelincahan Rendah}

Hipotesis kedua berbunyi "ada perbedaan peningkatan keterampilan bermain bulutangkis antara kelincahan tinggi dan kelincahan rendah". Dalam uji ini menggunakan uji t, dengan kriteria pengujian adalah apabila nilai Sig lebih besar dari 0,05. Diperoleh nilai $t$ hitung sebesar 2,901 dengan nilai Signifikansi 0,008 . Ternyata nilai Sig yang diperoleh lebih kecil dari 0,05. Dengan demikian dapat disimpulkan bahwa hipotesis diterima, artinya ada perbedaan peningkatan keterampilan bermain bulutangkis antara kelincahan tinggi dan kelincahan rendah.
Ada Interaksi antara Metode Latihan dan Kelincahan terhadap Keterampilan Bermain Bulutangkis

Hipotesis ketiga berbunyi "ada interaksi antara metode latihan dan kelincahan terhadap keterampilan bermain bulutangkis". Untuk uji interaksi antara variabel, apabila probabilitas > 0,05 maka antar variabel tidak ada interaksi. Apabila probabiltas $<0,05$ maka antar variabel terdapat interaksi. diperoleh bahwa nilai $\mathrm{F}$ hitung pada interaksi metode latihan dan kelincahan sebesar 0,553 dengan nilai Signifikansi yang diperoleh sebesar 0,466 adalah lebih besar dari 0,05 ( $p>0,05)$.

Didapat probabilitas 0,466 maka dapat disimpulkan bahwa hipotesis ditolak, artinya tidak ada interaksi antara variabel metode latihan dan kelincahan $(0,466>0,05)$.

Pembahasan

Penelitian ini bertujuan untuk mengetahui perbedaan pengaruh latihan metode drill dan latihan strokes terhadap keterampilan bermain bulutangkis atlet tingkat pemula, mengetahui perbedaan peningkatan keterampilan bermain bulutangkis antara kelincahan tinggi dan kelincahan rendah atlet tingkat pemula, mengetahui pengaruh metode latihan dan kelincahan terhadap keterampilan bermain bulutangkis atlet tingkat pemula, dan mengetahui interaksi antara metode latihan dan kelincahan terhadap keterampilan bermain bulutangkis atlet tingkat pemula.

Hasil pengujian hipotesis yang pertama diperoleh hasil bahwa hipotesis diterima, yaitu ada perbedaan pengaruh latihan metode drill dan latihan strokes terhadap keterampilan bermain bulutangkis atlet tingkat pemula. Hal ini dikarenakan pada latihan metode drill anak latih ditekankan untuk mengulang gerakan sampai benar. Selain itu pada metode drill juga sesekali dilakukan koreksi sehingga gerakan yang dilakukan semakin benar. Atlet berkonsentrasi pada kebenaran gerakan, situasi disesuaikan dengan permainan sesungguhnya, dan juga bersifat kompetitif. Anak latih juga dituntut melakukan gerakan sesuai apa yang diinstruksikan oleh pelatih, dan melakukannya berulang-ulang. Misalnya di dalam melatihkan suatu pukulan dalam bulutangkis, pelatih menetapkan tujuan latihan yaitu anak latih mampu melakukan keterampilan pukulan dalam bulutangkis. Dengan kata lain, anak latih mengikuti apa yang menjadi intruksi pelatih untuk menyelesaikan 
satu tugas terlebih dahulu kemudian baru beralih pada tugas berikutnya. Sedangkan pada latihan metode strokes latihan berupa serangkaian pukulan yang dilakukan secara berurutan dan berkesinambungan, sehingga gerakan demi gerakan tidak dikoreksi secara satu per satu. Jadi dalam pengujian hipotesis pertama yaitu kedua metode memiliki pengaruh, namun pengaruh yang paling besar pada metode drill.

Pada pengujian hipotesis kedua diperoleh hasil bahwa hipotesis diterima, sehingga dapat disimpulkan bahwa ada perbedaan peningkatan keterampilan bermain bulutangkis antara kelincahan tinggi dan kelincahan rendah atlet tingkat pemula. Kelincahan merupakan kemampuan seseorang dalam merubah arah dan posisi tubuhnya dengan cepat dan tepat pada waktu bergerak, sesuai dengan situasi dan kondisi yang dihadapai di lapangan tertentu tanpa kehilangan keseimbangan tubuh. Menurut Ismaryati (2008, p.76) bahwa kelincahan didefinisikan sebagai kemampuan untuk mengubah kecepatan dan arah posisi tubuh atau bagianbagiannya dengan cepat dan tepat, sementara perpindahannya dengan cepat tanpa kehilangan keseimbangan. Kelincahan merupakan komponen fisik untuk menunjang keterampilan bermain bulutangkis yang dipengaruhi oleh beberapa faktor. Kelincahan juga dipengaruhi oleh beberapa faktor, yaitu: Ada faktor yang mempengaruhi kelincahan yaitu kekuatan otot, kecepatan, tenaga ledak otot, waktu reaksi, keseimbangan, dan koordinasi. Kelincahan yang baik dapat memberikan gerakan yang cepat dan tepat. Jadi agar dapat bermain bulutangkis dengan baik harus memiliki kelincahan yang baik.

Hasil pengujian hipotesis ketiga diperoleh hasil bahwa hipotesis ditolak, sehingga disimpulkan tidak ada interaksi antara metode latihan dan kelincahan terhadap keterampilan bermain bulutangkis. Berlawanan dengan hasil hipotesis yang kedua, bahwa jika keterampilan bermain bulutangkis yang baik dipengaruhi oleh kelincahan yang baik. Menurut analisis peneliti dari hasil penelitian menunjukan bahwa tes keterampilan bermain bulutangkis milik Verducci memiliki kelemahan dalam hal kelincahan yang kurang terukur. Selain itu tes keterampilan bermain bulutangkis ini memiliki karakteristik metode latihan drill yaitu melakukan gerakan yang sama dan tidak banyak bergerak ke samping maupun ke depan dan ke belakang dalam melakukan tes keterampilan. Sehingga faktor kelincahan kurang terukur dan kurang berpengaruh dalam melaksanakan tes keterampilan. Hal ini menyebabkan tidak ada interaksi antara metode latihan dan kelincahan pada keterampilan bermain bulutangkis. Hal tersebut menggambarkan instrumen tes keterampilan bulutangkis yang dipergunakan memiliki karakteristik metode drill, yaitu gerakan dilakukan secara berulang-ulang dengan gerakan yang sama untuk menyelesaikan satu tugas terlebih dahulu kemudian melakukan tugas berikutnya.

\section{Simpulan dan Saran}

\section{Simpulan}

Berdasarkan hasil penelitian yang telah diperoleh dengan analisis data, maka dapat ditarik kesimpulan sebagai berikut: (1) Ada perbedaan hasil latihan pukulan antara metode drill dan metode strokes terhadap keterampilan bermain bulutangkis atlet tingkat pemula, bahwa latihan metode drill lebih baik daripada metode strokes, (2) Ada perbedaan hasil latihan pukulan antara kelincahan tinggi dan kelincahan rendah keterampilan bermain bulutangkis atlet tingkat pemula, bahwa kelincahan tinggi lebih baik daripada kelincahan rendah, (3) Tidak ada interaksi antara metode latihan pukulan dan kelincahan terhadap keterampilan bermain bulutangkis atlet tingkat pemula.

\section{Implikasi Penelitian}

Berdasarkan hasil penelitian dan simpulan tersebut, penelitian ini mempunyai beberapa implikasi sebagai berikut: (1) Bagi praktisi bulutangkis dapat dijadikan tambahan pengetahuan tentang metode latihan pukulan yang tepat untuk menyusun program latihan, (2) Bagi pembaca, hasil penelitian ini dapat digunakan sebagai tambahan wawasan mengenai metode latihan guna meningkatkan keterampilan bermain bulutangkis, (3) Bagi penulis, dapat menambah wawasan ilmu pengetahuan, serta dapat mengaplikasikannya ke dalam pelatihan bulutangkis khususnya latihan pukulan.

\section{Keterbatasan Penelitian}

Penelitian telah dilakukan pembatasan masalah agar fokus dan tidak melebar. Namun demikian dalam melakukan penelitian terdapat kekurangan dan keterbatasan. Beberapa keterbatasan diantaranya sebagai berikut: (1) Tidak memperhitungkan masalah kondisi fisik dan mental responden pada waktu dilaksanakan tes, (2) Tidak memperhitungkan masalah waktu dan keadaan tempat pada saat dilaksanakan tes, (3) Dalam pelaksanaan latihan pada akhir sesi 
latihan bertepatan pada bulan puasa, sehingga anak latih kurang maksimal dalam melaksanakan program latihan, (4) Latihan di luar perlakuan tidak dapat dikontrol, sehingga memungkinkan porsi latihannya berbeda, (5) Instrumen tes keterampilan bermain bulutangkis tidak sesuai dengan faktor kelincahan, karena tes tersebut memiliki karakteristik drill.

Saran

Dengan mengacu pada hasil penelitian dan keterbatasan dalam penelitian, peniliti menyarankan: (1) Bagi pelatih, agar dapat memilih metode latihan yang tepat guna meningkatkan keterampilan bermain bulutangkisnya, (2) Bagi tim pelatih bulutangkis di klub-klub bulutangkis agar kreatif dalam menyusun rencana pembelajaran, dan dapat memilih metode yang tepat agar anak latih mau melaksanakan kegiatan yang disiapkan oleh pelatih, sehingga tujuan pembelajaran dapat tercapai, (3) Bagi pelatih, instrumen tes keterampilan bermain bulutangkis kurang tepat bilamana digunakan untuk mengetahui faktor kelincahan dalam pelaksanaan tes.

\section{Daftar Pustaka}

Agus Susworo Dwi M. (2005). Keterampilan mahasiswa dalam memukul pada olahraga softball. Majalah Ilmiah Olahraga, ISSN 0853-2273, Volume 11, April 2005, TH. XI, No. 1. Halaman 99. 116. Yogyakarta. Fakultas Ilmu Keolahragaan. Universitas Negeri Yogyakarta.

Ary, Donald., Jacobs, Luchy C., Razavieh, Asghar. (2007). Pengantar penelitian dalam pendidikan. (Terjemahan Arief Furchan). Yogyakarta: Pustaka Pelajar Offset.

Birch, K., MacLaren, D., \& George, K. (2005). Sport \& exercise physiology. New York: Madison Avenue NY 10016. USA

Bompa, O. Tudor and G. Gregorry Haff. (2009). Periodization: theory and methodology of training. New York. United State of America.

Davis, Pat. (1996). Play the game badminton. London. Blandford: Wellington house. 125 Strand.
Irianto, Djoko Pekik. (2002). Dasar kepelatihan. Yogyakarta: Universitas Negeri Yogyakarta.

Ismaryati. (2008). Peningkatan kelincahan atlet melalui penggunaan metode kombinasi latihan sirkuit, pliometrik dan berat badan. Jurnal. PAEDAGOGIA, Jilid 11, Nomor 1, Februari 2008, halaman 7479.

Miller, David Keith. (2002). Measurement by the physical educator: why and how. University of North Carolina at Wilmington. Mc Graw Hill.

PP. PBSI. (2001). Pedoman praktis bermain bulutangkis. Jakarta: PP. PBSI.

PP. PBSI. (2012). Sistem ranking PBSI. Jakarta: PP. PBSI.

Purnama, Sapta Kunto. (2010). Kepelatihan bulutangkis modern. Surakarta: Yuma Pustaka.

Subarjah, Herman. (2011). Permainan bulutangkis. Bandung: CV. Bintang Warli Artika.

Sukadiyanto. (2005). Pengantar teori dan metodologi melatih fisik. Yogyakarta: Universitas Negeri Yogyakarta.

Sutrisna, Budi., \& Khafadi, Muhammad Bazin. (2010). Pendidikan jasmani olahraga dan kesehatan 2. Jakarta. CV. Putra Nugraha. Di ambil dari: http://www.scribd.com/doc/104170779/ BukuBse-belajarOnlineGratis-comPenjaskes2-Smp-Mts-VIII-Budi-1.

Widiastuti. (2011). Tes dan pengukuran olahraga. Jakarta Timur: PT. Bumi Timur Jaya. 